\title{
EFFORTS TO IMPROVE THE ABILITY OF READING EARLY AGE CHILDREN THROUGH THE METHOD OF SINGING
}

\author{
Wawa Wartini \\ IKIP Siliwangi \\ wawairwan7@gmail.com
}

\begin{abstract}
Language is a very important tool in the child's life, because with the language of children can communicate with others, the language aspect developed is reading in early childhood. Early reading can be said of the early ability to pass the child in the process of mastering the ability to read thoroughly. This encourages researchers to conduct a study on efforts to improve early childhood reading skills in Paud Sri Rejeki in Rw 06 Rt 03 Setiamanah village, Cimahi district, Central Cimahi city. The research is based on the problems found in Paud Sri Rejeki Rw 06 group B that is the ability to read the children who mostly are in the less category. The purpose of this research is to know the ability of children to read early before, during learning process, and result of reading ability of early child after using method of singing. The method used is descriptive study with qualitative approach. Subjects in this study were students Paud Sri Rejeki Rw 06 Cimahi which amounted to 5 people. The data collected is data of observation, interview and documentation study. The results showed that the use of singing method can improve reading ability of early child so that children can recognize letters, recognize words, and know the sentence. In other words, the method of singing can increase interest in reading early childhood.
\end{abstract}

Keywords: Early Childhood, Reading Ability, Method of Singing.

\section{A. INTRODUCTION}

Early childhood development is a very decisive period for the lives of children in the future. This period can be said to be a very fundamental period for the life of the next child, because at this time the rapid development of children, especially in the cognitive, language, social, motor and physical aspects.

Paud is a form of early childhood education in the path of non-formal education for children ages four to six years. Early childhood education is essentially education that is organized with the aim of facilitating the growth and development of children as a whole. The development of language skills in PAUD aims to enable children to communicate effectively and generate interest in being able to speak good Indonesian. Language is an important communication tool in human life, language is used to express thoughts, ideas, information, and feelings to others in the form of symbols or symbols such as using oral, written, numbered gestures and facial expressions.

Language skills according to (Tarigan, 1993: 1) consist of listening skills, reading skills, speaking skills and writing skills. Reading skills at PAUD can be carried out based on the basic principles of early childhood education, namely through playing. 
Looking at the phenomena occurring in the field, especially in the Paud Sri Rejeki Rw 06 in Setiamanah village, central Cimahi., the learning process to improve children's reading skills is less varied and pleasant so that children appear to be less responsive, because improving reading skills gives children more direct reading methods. . Conditions like this are felt to be unpleasant, because Paud's children generally like to play.

Moving on from the problems above, the writer will try to develop the children's reading skills through the use of syllables through singing methods to foster children's reading interest in language learning. Reading hobby must be developed early, this is considering the basic potential that must be owned by each child.

The study provides identification of problems in the form of methods used by teachers in an effort to improve children's reading skills through the singing method in the B Paud Sri fortune Rw 06 in the village of Setiamanah in central Cimahi. Based on the problems mentioned above, several problems can be identified. As for problems that can be identified as follows:

1. Not yet optimal reading ability of early childhood on Paud Sri Rejeki Rw 06 in Setiamanah village, central Cimahi.

2. Not yet optimal way of teaching reading in early childhood through the method of singing on Paud Sri fortune Rw 06 in the village of Setiamanah in central Cimahi.

3. There are signs of the difference in reading ability of early childhood before and after the learning process using the method of singing on Paud Sri fortune Rw 06 in the Setiamanah sub-district of central Cimahi.

\section{B. THEORITICAL REVIEW}

Basically all children in this world especially in early childhood wherever they come from have the same penchant for playing. Playing is an activity that is unique and very different from other activities such as work that is often done by adults in achieving an end result. Thus the knowledge of learning theory and the learning process for early childhood is very beneficial not only for teachers in PAUD institutions, but also has benefits for parents and adults who have the responsibility to teach their children wherever and whenever they are. Every child born has been equipped with a number of language capacities or potential. The potential of this language will develop when the time comes. Every child born is also equipped with a tool called LAD (Language Acquisition Device) which is translated here as a Language Acquisition Tool (PPB).

The sensitive period of child development is the initial period for learning, namely through the stages of interest and curiosity in something. This period cannot come a second time or repeat. During this period the interest of children is getting higher and the child becomes sensitive or easily stimulated towards the environmental aspects that are around him. Thus, it is important for an educator to understand this process because each stage has opportunities that are beneficial for children's development. The world of children is the world of play, which is a very interesting phenomenon for educators, psychologists, and philosophers long ago.

Talk is a form of language that uses articulation or words that are used to convey intentions (Tarigan , 1993: 3) that speaking is the ability to say sounds of articulation or words to express, express and convey thoughts, ideas, and feelings. Storytelling method means telling 
stories by speaking. What distinguishes between telling stories with other methods of telling stories is the more prominent technical aspects of storytelling.

The development of speech is a process that uses expressive language in forming meaning. The study of the development of speech in children is inseparable from the fact that there are differences in the speed of speech, as well as the quality and quantity of children in producing language (Dhieni, 2007: 3).

Language development is one of the scopes of developing the formation of behavior that must be developed in early childhood. Most patterns of language development in children are only obtained through conversation interactions, as well as dialogue with adults. (Agung et al., 2015:1). Playing in a school setting can be described as a range of unity that ends in free play, playing with guidance and ending with playing directed. In directed play, the teacher teaches how to complete a specific task, such as singing a song, along with playing fingers and playing in a circle are examples of directed play. Ability is ability, the power to do something ability is also something that someone wants to achieve in doing something. Language development is best when children act as conversation partners and enter into real conversation or dialogue. However, there is always a difference in language between one child and another child. Moreover, if the child is influenced by a culture that is unique from his social life ". children's language skills can be improved through activities to retell the story content of children aged 4-5 years in the play group (Fauziddin, 2017: 42). Children will be able to express their thoughts through simple language correctly (Depdiknas, 2006).

The method comes from the Greek "Methodos" which means the way or path that is taken. In connection with scientific endeavors, the method concerns the problem of how to work to be able to understand the objects that are subject to the relevant knowledge. According to (Nuraeni, 2013: 46) interpreting qualitative descriptive method is a method in examining the status of a group of humans, an object, a condition, a system of thought, or a class of events in the present. Methods of early childhood learning are ways or techniques used so that learning objectives are achieved. The use of appropriate teaching methods and in accordance with the character of children will be able to facilitate the development of various potentials and abilities of children optimally and the growth of positive attitudes and behaviors for children. (Depdiknas, 2003) further complements the benefits of other learning media, namely; media can make abstract subject matter more concrete, media can overcome constraints of space and time constraints, media can help overcome the limitations of the human senses media can present learning objects in the form of rare and dangerous objects or events into the classroom, and the media can give a deep impression and longer stored in students.

Reading is a fundamental ability that must be possessed by children in order to be able to obtain information through written media for the survival of the child further. Most learning activities are filled with reading activities. So, mastering the ability to read for children will greatly help children to get the opportunity to get and understand various knowledge earlier. Reading the beginning is the ability to recognize letters one by one and combine these letters into simple words (Ratnasari, 2017: 1).

Reading in early childhood is more emphasized in the preparation of reading or the initial stage of the child to be able to read in further education which is more emphasized in the introduction of known letter symbols to understand the meaning of the words in the story. The ability to read the child's beginning will develop along with the child's mental and 
cognitive development. This is because children will find themselves from their experiences in accordance with what is seen and what is heard. Children will be able to express their thoughts through simple language correctly (Depdiknas, 2006). Language learning in Kindergarten (TK) is directed at developing children's ability to communicate in Indonesian, namely the ability to listen, speak, write and read. This is in accordance with what was stated by (Tarigan, 1994: 1), for that, what can be done is an effort to introduce letters, which is the basis for reading. Raines and Canad dalam (Dhieni, 2007: 3.17)

According to Heinich, Molenda, and Russell in (Badru, 2008: 26) "Media is a communication channel. Media comes from Latin and is a plural form of the word medium which literally means intermediary, namely intermediary source message (a saurce) with the recipient message (a receiver). Learning media always consists of two important elements, namely elements of equipment or hardware (hardware) and the elements of the message it carries (message / sopfware). In early childhood learning situations there are messages that must be communicated. The message is usually the content of the theme or topic of learning. learning media is everything that can channel messages, can stimulate the thoughts, feelings, and willingness of students so that it can encourage the creation of learning processes in students.

\section{Media Singing}

Media are various types of components in the student environment that can stimulate them to learn. Through learning media which is a component to stimulate student learning, the learning media used in this study are singing media. (Depdiknas, 2003) further complements the benefits of other learning media, namely; media can make abstract subject matter more concrete, media can overcome constraints of space and time constraints, media can help overcome the limitations of the human senses media can present learning objects in the form of rare and dangerous objects or events into the classroom, and the media can give a deep impression and longer stored in students.

Singing is an activity to express the feeling that is in human beings through tone and words. From some experts' opinions, it was concluded that the singing method is a method that emphasizes the words that are sounded in a pleasant atmosphere so that the child does not feel bored.

In providing teaching reading skills using the singing method, there are several steps that must be taken by the teacher and child in conducting this learning activity. The methods used in the singing method are three methods, namely the overall method, the method of methods and mixed methods (Ministry of National Education, 1996: 65).

\section{RESULTS AND DISCUSSION}

\section{Result}

This study aims to examine how the efforts to improve early childhood reading skills through the method of singing on Paud Sri Fortune RW 06 in the Setiamanah sub-district of central Cimahi. Presentation of data from the results of this study relates to objective conditions. Paud Sri Rejeki is one part of Paud who was in the city of Cimahi, precisely located on the RT 03 RW 06 in Setiamanah village, Cimahi sub-district, Cimahi city, West Java Province. 
Paud Sri Rejeki consists of two groups, namely group A aged 3-5 years and Group B aged 56 years with a total of around 102 students. The Learning Process to teach Paud Sri Rejeki was held at the Daarur Rohman TPA

a. Implementation of Early Childhood Reading Learning Activities in Paud Sri Rejeki Rw 06 Setiamanah Village Cimahi Tengah.

Learning activities for early childhood, especially learning activities to increase interest in reading early childhood, should be prepared by education in a holistic situation by using strategies, methods, materials / materials, and media that are interesting and easy for children to follow. Early reading can be said to be the initial ability passed by the child in the process of mastering the ability to read thoroughly.

The use of teaching methods and assisted with appropriate and accurate learning media will be able to develop children's language skills, in addition children will feel happy and relaxed while doing reading learning activities. Learning activities in children must always be narrated to the needs of children.

Looking at the phenomena occurring in the field, especially in the B Paud Sri Rejeki RW 06 kelurahan of Setiamanah, Central Cimahi, the learning process to improve children's reading skills is less varied and pleasant so that children appear to be less responsive, because improving reading skills gives children more direct reading methods. . Conditions like this are felt to be unpleasant, because Paud's children generally like to play.

b. Improving Teaching Reading in Early Childhood Through the Method of Singing at Paud Sri Rejeki Rw 06 Setiamanah Village, Cimahi Tengah.

Furthermore, to improve the ability to read early childhood in learning activities through singing methods needs to be improved so that there is an increase in the scientific field of early childhood education, so that it can provide scientific contributions to improve early childhood reading skills through singing methods. In Paud Sri Rejeki began to be applied to the use of the singing method in order to increase interest in reading early childhood, and it was seen a fairly good response from children and cognitively seen children more quickly remember syllables in the language.

c. Interview Results How the Results of Early Childhood Reading Ability After Using the Singing Method in Paud Sri Rejeki Rw 06 Setiamanah Village, Cimahi Tengah.

From the results of interviews conducted by researchers on the two teachers, it can be concluded that the teaching in developing interest in reading early childhood at Paud Sri Rejeki has used many letters and syllables directly to children, so that many children do not respond and the results there are children who are very difficult to read and also lack the availability of learning media and facilities that are less supportive in learning to know the language to increase children's reading interest, even though the age of group B children must be prepared especially in reading to enter the next level, namely elementary school. 


\section{Discussion}

Reading is a fundamental ability that must be possessed by children in order to be able to get information through written media for the survival of the child further. Children like to follow the rhythm and sing, children show spontaneous desires in the symbols and voices that are released soon after they speak the words. Singing is an activity to express the feeling that is in human beings through tone and words.

From the results of interviews conducted by researchers on the two teachers it can be concluded that children are still unable to distinguish syllables, interest in reading and singing children is still lacking, and the use of instructional media is only letters and reading books for early childhood, so there are children who are hard to read. Paud Sri Rejeki actually has been using the singing method but because of lack of vocabulary new songs have resulted in less varied teaching, and early childhood learning has begun to be applied to increase children's interest in reading with the singing method and given new song variations and shown letters and syllables so that children respond quickly and remember and feel happy.

Learning by using singing methods accelerates children to recognize and show consonants, compose simple words, arrange simple sentences and read simple words and sentences. This is because one of the learning processes is fun and can be easily accepted by children rather than information that is compelling by looking and listening, but the child directly applies it.

From the results of interviews conducted by researchers on the two teachers, it can be concluded that the results of early childhood reading skills after using the singing method on Paud Sri Rejeki Rw 06 in the Setiamanah sub-district of Cimahi Tengah, seen from the learning results after using the singing method, showed sufficient response good from children so there is an increase that is so fast, children recognize letters and syllables faster. And can increase children's reading interest. But learning must be further improved, especially in improving the syllable singing practice and word consonants so that the child's stimulus is rapidly developing, so as to increase the interest in reading early childhood.

\section{CONCLUSION}

Based on the results of research on "Efforts to Improve the Reading Ability of Early Childhood Through the Singing Method" conducted at Paud Sri Rejeki Rw 06 Rt 03 Setiamanah Village, Central Cimahi District, Cimahi City. Can be concluded that :

1. The initial condition of developing interest in reading early childhood on Paud Sri Rejeki Rw 06 before conducting research using the singing method has not experienced development in learning, and the learning process to increase interest in reading children is less varied and pleasant so that children are less responsive and enthusiastic, because in increasing interest in reading children prioritize direct reading methods. This condition in recognizing words, composing words, remembering words, imitating 1-2 simple words, differentiating words, connecting and mentioning simple writing with symbols that symbolize it, children are so difficult in accepting the learning given by the teacher. Such conditions are felt to be unpleasant, because early childhood in Paud generally like to play. 
2. In the implementation of learning in Paud Sri Rejeki Rw 06, the use of teaching methods and assisted with appropriate and accurate learning media will be able to develop children's language skills, in addition children will feel happy and relaxed when doing reading learning activities. Learning activities in children must always be narrated to the needs of children. In Paud Sri Rejeki began to be applied to the use of the singing method in order to increase interest in reading early childhood, and it was seen a fairly good response from children and cognitively seen children more quickly remember syllables in the language.

3. The method of singing letters and words has contributed and influences the level of reading ability of early childhood on Paud Sri Rejeki Rw 06. The results of this study indicate that the use of singing methods can improve the reading ability of early childhood, so that children can recognize letters, recognize the word, and recognize sentences.

\section{E. REFERENCES}

Agung dkk. (2015). Meningkatkan perkembangan bahasa melalui model pembelajaran kooperatif time token berbantuan media flash card pada anak kelompok B Tk kemala Bhayangkari Denpasar. e-Journal PG-PAUD Universitas Pendidikan GaneshaJurusan Pendidikan Guru vol-3 No 1.

Depdiknas. (2006). Pedoman Pembelajaran ditaman kanak-kanak. Jakarta : Depdiknas. Depdiknas. (2003). Pedoman Pembelajaran ditaman kanak-kanak. Jakarta : Depdiknas. Depdiknas. (1996). Pedoman Pembelajaran ditaman kanak-kanak. Jakarta : Depdiknas. Dhieni, (2008). Metode Pengembangan Bahasa. Jakarta : Universitas Jakarta.

Ratnasari. (2017). Pengembangan Media Visual Kartu Angka Efektif Untuk Mengenalkan Huruf Vokal a, $i$, u, e, o Pada anak usia dini 3-4 tahun Paud Labshool Jember. Jurnal Ilmiah Pendidikan PraSekolah dan Sekolah Awal. INDRIA

Fauziddin.(2017). Upaya Meningkatkan Kemampuan Bahasa Anak Usia 4-5 tahun Melalui Kegiatan Menceritakan Kembali Isi Cerita di Kelompok Bermain Aisyiyah Gobah Kecamatan Tambang. Jurnal Obsesi, 42-51.

Nuraeni. (2013). Memahami penelitian Ilmiah. Bandung: STKIP Siliwangi Bandung. Tarigan (1990). Membaca Sebagai Suatu Keterampilan Berbahasa. Bandung:Angkasa. Zaman. (2008). Media dan Sumber Belajar TK. Jakarta: Universitas Jakarta. 